\title{
Effect of Ramadan Fasting on Renal Functions in Type 2 Diabetic Patients
}

\section{(P-0450)}

Manal Abushady*, Merhan Samy*, Meram M. Bekhet ${ }^{\star}$, Asmaa Abdullah $^{\star \star}$

${ }^{*}$ Division of endocrinology, Department of Internal Medicine, Ain Shams University Hospital, Cairo,

Egypt. " Department of Internal Medicine, Specialized Damietta Hospital.

\section{Background}

Ramadan fasting is a religious pillar carried out by Muslims all over the world. Concerns have been raised over how the practice of fasting from dawn to sunset affects kidney functions in diabetic Muslim patients as it represents a major shift in meal timing and content for practicing Muslims [1]. It is hypothesized that patients with diabetic kidney may experience worsening of their kidney functions [2-3].

\section{Aim}

We aimed to evaluate the effects of Ramadan fasting on kidney functions in type 2 diabetic patients.

\section{Subjects and Methods}

We recruited 90 subjects with type $2 \mathrm{DM}$ intending to fast Ramadan (2016); where the average fasting time was about 16 hours from 3 am to $7 \mathrm{pm}$ at temperature ranging from $37^{\circ} \mathrm{C}$ to $40^{\circ} \mathrm{C}$ with high humidity. They were divided into 30 subjects with albuminuria and renal impairment (group I), 30 subjects with albuminuria and normal kidney functions (group II) and 30 with normal kidney functions and no albuminuria (group III). Fasting blood glucose, 2hours plasma glucose, hemoglobin A1c, fructosamine, serum creatinine, BUN, Estimated glomerular filtration rate and albumin/ creatinine ratio were measured two weeks before and after Ramadan.

\section{Results}

On comparing the studied groups before and after fasting Ramadan, a significant reduction in HbA1c was found in all studied groups $(11.23 \pm 2.67 \%$ vs. $9.09 \pm 1.95 \%, 11.09 \pm 2.40 \%$ vs. $8.80 \pm 1.78 \%, 9.28 \pm$ $2.41 \%$ vs. $8.21 \pm 1.45 \%, p<0.001, p<0.001, p=0.04$ respectively). Regarding the kidney function parameters; there was no significant change in group I but there was a significant decline in these parameters in groups II and III; serum creatinine $(1.33 \pm 0.05 \mathrm{mg} / \mathrm{dl}$ vs. $1.41 \pm 0.23 \mathrm{mg} / \mathrm{dl}, 0.66 \pm 0.11 \mathrm{mg} / \mathrm{dL}$ vs. $0.93 \pm 0.17$ $\mathrm{mg} / \mathrm{dL}, 0.70 \pm 0.12 \mathrm{mg} / \mathrm{dL}$ vs. $0.84 \pm 0.16 \mathrm{mg} / \mathrm{dL}$, $\mathrm{p}=0.101, p<0.001, p<0.001$ respectively), eGFR (63.07 \pm $3.27 \mathrm{ml} / \mathrm{min} / 1.73 \mathrm{~m}^{2}$ vs. $59.73 \pm 13.25 \mathrm{ml} / \mathrm{min} / 1.73 \mathrm{~m}^{2}$, $114.00 \pm 18.74 \mathrm{ml} / \mathrm{min} / 1.73 \mathrm{~m}^{2}$ vs. $77.83 \pm 16.48$ $\mathrm{ml} / \mathrm{min} / 1.73 \mathrm{~m}^{2}, 111.70 \pm 18.60 \mathrm{ml} / \mathrm{min} / 1.73 \mathrm{~m}^{2}$ vs. 97.50 $\pm 21.19 \mathrm{ml} / \mathrm{min} / 1.73 \mathrm{~m} 2, \quad p=0.186, \quad p<0.001, \quad p=0.008$ respectively), urinary albumin/ creatinine ratio (88.40 \pm $64.86 \mathrm{mg} / \mathrm{g}$ vs $86.03 \pm 86.52 \mathrm{mg} / \mathrm{g}, 71.43 \pm 21.17 \mathrm{mg} / \mathrm{g}$ vs $112.33 \pm 72.40 \mathrm{mg} / \mathrm{g}, 16.18 \pm 7.99 \mathrm{mg} / \mathrm{g}$ vs $41.67 \pm$ $22.0 \mathrm{mg} / \mathrm{g}, \mathrm{p}=0.905, \mathrm{p}=\mathbf{0 . 0 0 4}, \mathrm{p}<0.001$ respectively). Regarding significant hypoglycemic events that led to breaking the fast and the need for dose reduction, they were significantley higher in group I when compared to groups II and III $(p<0.001, p=0.05)$ respectively.

Table [1]: Comparison between pre and post fasting according to laboratory data of the studied groups: $P>0.05$ : Non-significant (NS), $P<0.05$ : Significant $(S), P<0.01$ : Highly significant

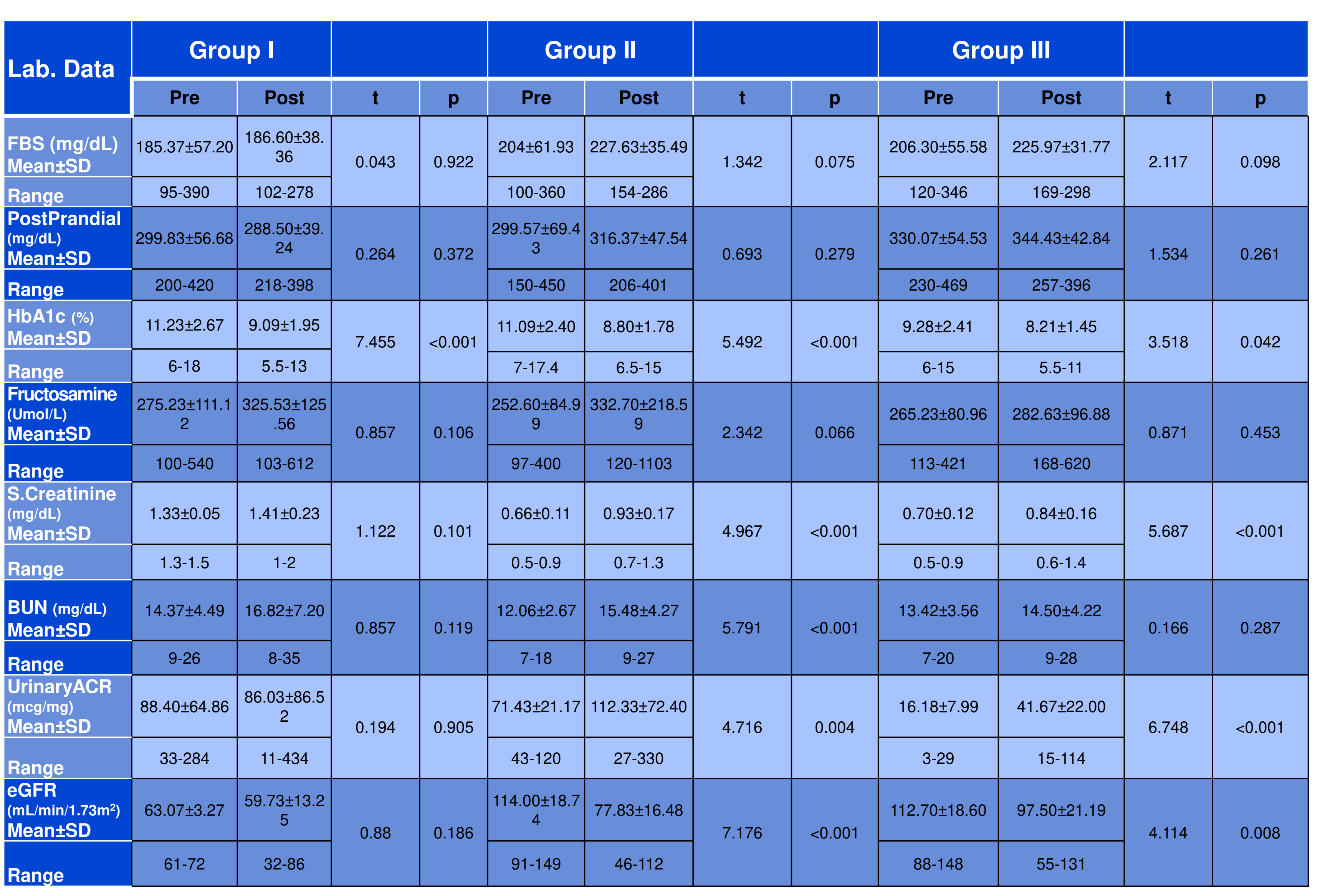

\section{Conclusion}

Ramadan fasting appears to a have significant effect on improvement of glycemic control in type 2 diabetic patients. There was a decline in kidney functions in patients with already existing albuminuria but without renal impairment unlike those having albuminuria with renal impairment this may be attributed to the conservative diet regimens and proper fluid intake of these patients for fear of further deterioration of their kidney functions. Patients with normal kidney functions showed decline in their eGFR but still within the normal range. Further studies on a larger scale are needed to assess the effect of Ramadan fasting on type 2 diabetic patients and the possible impact of balanced diet and fluid intake on the renal functions during fasting.

\section{References}

Jaleel MA, Raza SA, Fathima FN and Jaleel BN (2011). Ramadan and diabetes: As-Saum (The fasting). Indian J Endocrinol Metab; 15:268-73. chronic kidney disease prospective observational study. Saudi Med J; 38(1): 48-52. NasrAllah M (2014). Fasting during the month of Ramadan among patients with chronic kidney disease: renal and cardiovascular outcomes. Clin Kidney J; 7(4): 348-353. 